\title{
REB'-İ REŞîDÎ HANKÂHINDA İKİ ÂRIIF: KĀŞÂNî VE DÂVÛD-İ KAYSERî
}

\begin{abstract}
Abdurrahim Alkış*
$\ddot{\mathbf{O} z}$

Dâvûd-i Kayserî, aslen Tahran'a yakın Sâve şehrinden gelmiş bir âilenin ferdi olarak Kayseri'de doğmuş, ilk tahsîlini Anadolu'da görmüş ve ardından Mısır'a gitmiştir. Mısır seferinden sonra tekrar Anadolu'ya dönen Kayserî, hayatının on yılı aşkın bir kısmını Tebrîz'in meşhur Reb'-i-Reşî̂i semtinde (kampüsünde) geçirir. İleri yaşına rağmen burada hem talebelik hem de hocalık yapar. Dönemin önemli âriflerinden olan Abdürrezzâk-1 Kāşânî'den Füsûs ve Te'vîlât dersleri alır. Kayserî tasavvuf çevrelerince çokça tutulan Füsûs Şerhi'ni ve birkaç eserini bu kampüs içerisinde bulunan hankāhta kaleme alır. Hankāhın kurucusu İlhanlı veziri Reşîdüddîn Fazlullah ve Reşîdüddîn'in oğlu Ğıyâseddîn Muhammed ilim ehline aşırı ihtimâm göstermişler bu bağlamda hem Kayserî'ye hem de Kāşânî'ye oldukça önem vermişler ve onlara ilmî faaliyetler için çok iyi bir ortam hazırlamışlar. Binâenaleyh her iki ârif de birçok eserini ona ithâm ederek kaleme almıştır. Biz bu çalışmamızda Kayserî’nin hayâtı hakkında bâzı bilgiler verdikten sonra ismi geçen zatlar arasındaki ilişkiyi irdelemeye çalışacağız.
\end{abstract}

Anahtar Kelimeler: Dâvûd-i Kayserî, Kāşânî, Tebrîz, Reb'-i Reşîlî

TWO SCHOLARS IN THE HANKAH OF RAB'-I RASHÎDÎ: KASHÂNî AND DÂVÛD-I KAYSER̂̂

\begin{abstract}
Dâvûd-i Kayserî was born in Kayseri as a member of a family originally from the city of Sâve, close to Tehran, he saw his first education in Anatolia and then went to Egypt. Returning to Anatolia after the Egyptian voyage, Kayserî has spent more than ten years of his life in the famous Rab'-i-Rashîdî district (campus) of Tabrîz. Despite his advanced age, he is both a student and a teacher here. He takes Fusus and Ta'vîlât lessons from Abd al-Razzaq al-Kāshânî, who is one of the important scholars of the period. He wrote the sharh of Fusus, which was very popular among Sufi circles, and a few of his works in the hankāh in this campus. The founder of Hankāh, İlhanlı vizier Rashîdiddîn Fazlullah and the son of Rashîduddîn, Giyâsaddîn Muhammad paid great attention to the people of science, in this context, they gave great importance to both Kaysari and Kāshânî and prepared a good environment for them for their scientific activities. Thus, both scholars wrote many of their works by dedicating to him. In this study, after giving some information about the life of Kaysari, we will try to examine the relationship between the mentioned people.
\end{abstract}

Keywords: Dâvûd-i Kaysarî, Kāshânî, Tabrîz, Rab'-i Rashîdî

Article Types / Makale Türü: Research Article / Araştırma Makalesi

Received / Makale Geliş Tarihi: 16/09/2020, Accepted / Kabul Tarihi: 01/12/2020

DOI: https://doi.org/10.26791/sarkiat.795958

* Dicle Üniversitesi İlahiyat Fakültesi Tasavvuf Anabilim Dalı Öğretim Üyesi, Diyarbakır. abdurrahim.alkis@dicle.edu.tr

ORCID ID: https://orcid.org/0000-0002-6125-8625 


\section{GíRiş}

Târîh boyunca idâre sınıfının hayatın bütün alanlarında etkisi olduğu gibi ilmiyye sınıfı üzerinde de büyük etkisi olmuştur. Ünlü devlet adamı İlhanlı Vezîrî ve Bilge adam Reşîüddîn Fazlullâh-1 Hemedânî'nin ${ }^{1}$ de belirttiği gibi elinde askerî gücü bulunduran tâife ekonomiyi kontrol etmiş, ekonomiyi kontrol edip düzenleyenler de âlimleri ve halk1 egemenlikleri altında bulundurmuştur. Halk üzerinde egemenliği sürdürmek için de bir yerden sonra yöneticilerin yânî devletin adâletli olması îcâp etmiştir. Bu devriyenin sağlam çarklar ile dönmesi için de ilmiye teşkilatına ihtiyaç hissedilmiştir. Bu çalışmamızda bir nebze de olsa "idâreciler" ile "sûfîlerin de içerisinde yer aldığı ilmiyye teşkilatı" ilişkisini Dâvûd-i Kayserî ve Abdürrezâk-1 Kāşânî örneği müvâcehesinde ele alacağız. İlk önce Kayserî'nin hayatı hakkında bâzı kısa bilgiler arz edeceğiz. Ardından İlhanlar döneminin en büyük üniversitesi konumunda bulunan Reb'-i Reşîdî Kampüsü ve burada bulunan hankāh hakkında bâzı bilgiler sunacağız. Bir sonraki adımda da Dâvud-i Kayserî'nin bu hankāhta rahle-i tedrîsinde bulunduğu hocası Abdürrezzâk-1 Kāşanî (v. 1335) ile olan irtibâtını ve te'sîr-teessürünü îzâh etmeye çalışacağız. En son olarak da Kayserî'nin İznik’teki müderrislik günlerine bakacağız.

Dâvud-i Kayserî’nin hayat hikâyesine baktığımızda onun beş ayrı hükümdârlık sahasında yaşadığını görüyoruz.

$\begin{array}{ll}\text { - } & \text { Anadolu Beylikleri Dönemi’nde (İlhânlı ve Memlüklülerin Te'sîrinde) } \\ \text { - } & \text { Misır Memlûkler Dönemi'nde } \\ \text { - } & \text { İlhanlı Emirleri Dönemi’nde } \\ \text { - } & \text { İlhanlıların Merkezi Olan Tebrîz'de Reb'-i Reşî̀î Hankāhı'nda } \\ \text { - } & \text { Osmanlılar Dönemi'de İznik Medresesi’nde. }\end{array}$

\footnotetext{
${ }^{1}$ Reşîdüddîn Tabîb Fazlullah Hemedanî nisbesinde de anlaşılacağı üzere, Hemedan'da dünyaya gelir. Vilâdeti 645 (1247), şeklinde bilinir. Moğol hükümdârlarından Abaka Han devrinde (1265-1282) doktor olarak yönetimin emrine gire ve Argun Han zamanında (1284-1291) yerini güçlendirir. Gâzân Han'ın hükümdârlığı döneminde Vezir Sadreddin Zencânî'nin öldürülmesinden sonra Sa'deddîn-i Sâvecî berâberinde vezirlik vâzifesini deruhte der. (697/1298). Gâzân Hân'ın ilk (699/1300) ve üçüncü (702/1303) Şam fethi savaşı çalışmalarına katılır. Devletin kurumlarında reformlar yapar.Moğol sultanı Gâzân Hân'ın Tebriz'de inşâ etmek istediği Şenb-i gâzân Külliyesiyle o ilgilenir. Gāzân Hân, hayatının son yıllarında Reşîüüddîn'in mânend Sa 'deddîn-i Sâvecî'ye çok önem vermeye başlar. Reşîdüddîn Fazlullah, Gâzân Hân oldukten Sultân Olcaytu'nun yanında çalışmaya başlar ve ilme ve âlimlere büyük önem verir. Olcaytu döenminde Reşîdüddîn'in devlet idâresi içersindeki yeri iyice pekişir., Sultân Olcaytu Hân onun sâyesinde Şâfiî mezhebine iktidâ eder. Devlet yönetimi içerisinde yükselmesi Sa‘deddîn-i Sâvecî’yi kızdırır. Çok geçmeden Sa 'deddîn-i Sâvecî bâzı suçalamalardan dolayı darağacına çekilir. Reşîdüddîn Fazlullah'ın çocukları Sultân Olcaytu zamanında devlet yönetiminde yüksek mevkilere getirilirler. Sultân Olcaytu'nun ölümünden sonra hân olan Ebû Saîd Bahâdır Hân döneminde işler Reşîüddîn'in aleyhine işler. Tâceddin Ali Şâh'ın isimli vezirin oyunları sâyesinde görevinden uzaklaştırılır. Reşîdüddîn Fazlullah (717/1317) yılında Sultân Olcaytu'nun zehirlenerek öldürülmesi işine karıştı̆̆g gerekçesiyle yargılanır. Tâceddîn Alî Şâh ve Emîr Çobân'ın aleyhte çabaları çabaları neticesinde Sultan Olcaytu Hân'ı zehirleyerek öldürdüğü suçlamasıyla oğlu İzzeddîn İbrâhim ile aynı gün darağacına asılır (17 Cemâziyelevvel 718 / 17 Temmuz 1318). Reşîüddîn'in cesedi Tebrîz caddelerinde Tebrîz'e ayakın bir yerde inşâ ettiği Reb 'i-Reşîlî yerleşkesine defn edilir. Bu arada malları yağmalanır, Reb'ireşîlî tahrîp edilir ve emlâkine el konularak vakıfları geçersiz sayılır. Malları ve vakfettiği malzemeye el konulur. Reşîdüddîn'in yirmiden fazla çocuğu vardı. Bunların bir kısmını devletin üst makamlarına getirmiş̧ti. Bunların içerisinde en başarılı olanlardan olan Ğıyâseddîn Muhammed, 1327-1335 seneleri mâbeyninde Ebû Saîd Bahâdır Hân'a vezîrlik yapmıştır. Çocukalrından Şeyhî, Sâtî Beg ve Mahmûd de Muzafferîler yönetiminin vezirliğini, Emîr Alî ise Bağdat emirliğini deruhte etmiştir. Reşîdüddîn Fazlullah çok zengin birisiydi Tebrîz’deki Reb 'i-Reşîlî hâricinde Tebrîz, Erdebîl, Hemedân, Sultâniye, Yezd, Merâga, Malatya ve Kayseri gibi pek çok yerde hayrât işlerinde bulunmuştur. (Bkz. Osman Gazi Güdenli, "Reşîdüddîn Tabîb", DİA (İstanbul: Türkiye Diyanet Vakfi, 2008), 35: 19-21.)
} 


\section{Dâvûd-i Kayserî’nin Doğduğu ve Yetiştiği Çevre (Beylikler Dönemi-İlhânlı- Memlûk Mücâdele Alanı):}

Osmanlı Medreseleri'nin kurucu rektörü mesâbesinde olan Dâvûd-i Kayserî aslen Sâve'li olup Kayserî'de doğmuştur. Âilesi Moğol saldırılarından kaçıp Kayserî’ye yerleşmiştir. Fakat ne yazık ki bu şehir de çok geçmeden çok şiddetli bir şekilde Moğol işgaline uğramıştır. Kayserî'nin doğum târihi hakkında net bir bilgi elimizde bulunmamaktadır. Rahle-i tedrisinde bulunduğu bâzı hocaların vefât târihlerinde yola çıkarak tahmînî bir rakam verebiliyoruz.

Hocaları ile ilgili bu bilgilerin ilk kaynakları Müneccimbaşı Ahmed b. Abdullah'ın Câmiu'd-Düvel ve Hoca Sa'deddin Efendî'nin Tâcü't-Tevârîh isimli eserleridir. Bu iki kaynağa göre Kayserî, Konya'nın meşhur Şâfî̂ kādısı Kādı Sirâceddîn-i Urmevî'den ders okumuştur. ${ }^{2}$. Urmevî'nin 1283 olan vefât târihi göz önünde bulundurulduğunda Kayserî'nin 1260'lı yıllarda doğduğu tahmin edebiliyoruz. Bu durumda Kayserî'nin yetmişli yaşlarında 1330'larda Reb'-i Reşî̂î Hankāhı'nda Abdürrezzâk-1 Kāşânî'ye (v. 23 Ağustos 1335) talebelik ettiğini söylemek zorundayız. Tabîatiyle bu da enteresan bir durum arz etmektedir. Vâkı, net bir bilgi elde edinceye kadar bu tahminle yetinmek zorunda kalacağız.

İbnü'l-Arabî düşüncesinin önemli şârihlerinden olan Dâvûd-i Kayserî 26 Mart 1332 târihinde Reb'-i Reşîlî Hankāhı'nda yazımını bitirdiği Füsûs Şerhi'nin ferağ kısmında, Kayserî şehrinde doğduğunu ve âilesinin buraya Sâve şehrinden hicret ettiğini bildirmektedir. Kayserî, Fusûs şerhinin müellif nüshâsında "el-Kayserî mevlîden esSâvî mehtidden" ifâdesini kullanmaktadır. "Mevlîd" -doğum yeri-, "mehtid" ise "aslen" mânâlarına gelir. ${ }^{3}$

Kayserî'nin hayâtı hakkında en önemli bir kaynaklarımızdan birisinin de müellifin yazma eserleri olduğunu söyleyebiliriz. Zîrâ müellif eserlerinin giriş bölümünde veya ferâğ kısmında kendisi ile ilgili bâzı bilgileri ve târihleri vermektedir.

İhsân Fazlıoğlu, Dâvûd-i Kayserî’nin Tokat-Niksâr'da istinsâh ettiği bazı eserlerden yola çıkarak Anadolu'daki hayâtı ile ilgili bir kısım iddiâlarda bulunmaktadır. ${ }^{4}$ Biz de Fazlıoğlu'nun bu iddialarından yola çıkarak ve yine yazma eserlerin giriş ve ferâğ kısımlarından istifâde ederek Dâvûd-i Kayserî'nin Tebrîz'deki Reb'-i Reşîîi Hankāhı yıllarını bir nebze de olsa açıklığa kavuşturmaya çalışacağız. Belirtmekte fayda var: Tebrîz şehri bu yıllarda, Osmanlı Beyliği dâhil Anadolu beyliklerinin bağlı olduğu

\footnotetext{
${ }^{2}$ Bkz. Sema Özdemir, Dâvud-i Kayserî'de Varlık, Bilgi ve İnsan (İstanbul: Nefes Yayınları, 2014), 29. $\mathrm{Bu}$ arada Anadolu Selçukluları ve Osmanlı'nın kuruluş döneminde resmî mezhebin ve halkın çoğunluğunun Şâfî̂-Eş'arî-Sûfî kimliğine sâhib olduğunu belirtelim. Anadolu'nun Hanefi mezhebine iktidâsı çok sonralarına denk gelmektedir. Görüldüğü üzere Anadolu Selçuklularının Kādı'l-kudât'1 Sirâceddîn Urmevî Şâfiî mezhebine müntesiptir.

${ }^{3}$ Bkz.Dâvûd b. Mahmûd b. Muhammed el-Kayserî, Müttalau Husûsi'l-Kelim fí Şerhi Fusûsi'l-Hikem, nr. no: 512, 128-b. Bâzı araştırmacılar Kayserî’nin eserinin isminde yer alan ilk kelimeyi "matla"” şeklinde de okuyabilmiştir. Orijinal nüshada ise bu kelime "müttala"” şeklinde harekelenmiştir. Eserin isminde yer alan "kelim” kelimesi de "kilem” şeklinde okunabilmiştir. Fakat İbnü'l-Arabî’nin Sadreddin-i Konevî’ye dikte ettirdiği Fusûs nüshasında ise bu kelime "kelim" şeklinde harekelenmiştir (Eserin orijinali İstanbul'da Türk ve İslam Eserleri Müzesi'nde 1933 numarada bulunmaktadır). Gramer ve mânâ açısından hem "kelim" hem de "kilem" de câizdir. Zîrâ ben-i temîm kabilesinin kırâatine göre "kelime"nin çoğulu "kilem" olarak okunur. Eserin ismindeki selâset açısından "kilem" şeklinde okunması daha uygun olsa gerek.

4 Bkz.Osman Fazlığlu, Osmanlı Coğrafyasında İlmî Hayâtın Teşekkülü ve Dâvud el- Kayserî (656 “660”/1258 “1262”-751/1350, (İbnü'l-Arabî Geleneği ve Dâvûd-i Kayseri kitabu içerisinde. Hzr: Turan Koç) (İstanbul: İnsan Yayınları, 2011), 26-38.
} 
İlhânlılar'ın başkenti konumundadır. Sultaniyye ve Reb'-i Reşî̀î gibi iki büyük kampüse meskenlik etmektedir.

Yukarıda belirttiğimiz üzere Dâvud-i Kayserî’nin âilesinin İran coğrafyasından Anadolu taraflarına gelmesi muhtemelen Moğol ordularının 1230'lardan itibâren İran'1 işgâlî ve katliâmlardan geçirmesi neticesindendir. Zîrâ bu dönemde milyonlarca insanın katledildiğini ve hayatını kurtarabilenlerin Anadolu ve Mısır taraflarına gittiği bilinen bir durumdur. 1243'te vukû bulan Kösedağ Savaşı'nda Selçukluların yenilmesi ile bu göç dalgalanması daha da şiddetlenmiştir. Bu asırda en büyük göç dalgası ise 1256'da Hülâgü'nün ağabeyi Mengü'nin batı taraflarına tayin edilmesi ile başlar. Netice olarak Anadolu coğrafyası bu savaşlardan dolayı iyice çalkalanmıştır. 1258'de İ́slâm âleminin başkenti konumundaki Bağdat işgâl edilmiş ve Abbâsî halifesi fecî bir şekilde şehîd edilmiştir. Bilindiği üzere Moğol saldırıları İbnü'l-Esîr'inde belirttiği gibi İnsanlık târihinin gördüğü en şiddetli zülümlerindendir. İşte Dâvûd-i Kayserî böyle bir ortamda İlhanlılar'a bağlı olan Kayserî şehrinde, büyük ihtimalle 1260'lı yıllarda, doğmuştur.

\section{Dâvûd-i Kayserî’nin Mısır Günleri (Memlûkler Dönemi):}

Davûd-i Kayserî'nin doğduğu dönemde gerçekleşen önemli bir hadîse 3 Eylül 1260 senesinde Ayn Câlût Savaşı'nda Memlûkler'in İlhanlıları mağlup etmesidir. Memlûk Sultânı Seyfeddîn Kutuz'un Moğol ordularını Filistin'de Ayn Câlût mevkisinde bozguna uğratmasıyla İlhanlıların ilerleyişi durmuş ve İslâm âlemi rahat bir nefes almıştır. O zaman kadar İslâm âlemini târ û mâr eden Moğollar yenilgi yüzünü tatmış ve ilk defa idarecileriyle birlikte ağlamaya başlamış ve kalblerine îmân nüveleri ekilmeye başlanmıştır.

Memlüklü'lerde Seyfeddin Kutuz'un sefer dönüşünde bir suikaste uğrayınca yerine Melik Baybars geçer. Melik Baybars sultan olduğunda karşısında İlhanlılar, Haçlılar ve Ermeniler olarak üç önemli düşman unsur bulur. Anadolu, Suriye ve Misır halkının dinî sebeplerden dolayı Moğollara olan düşmanlığı Melik Baybars'a güç verir. Zîrâ Moğullar Bağdadtaki Abbâsî Hilâfeti'ne son vermişti. Bu durumun yanı sıra İslâm Birliği'ni sağlama fikrini Eyyûbîler'den alan Memlûkler bu politika gereği Irak'ta Moğolların zülmettiği emirlere yardımda bulunur. Memlûklerin bu çabaları İslâm âleminde büyük sempati kazanır. Memlüklü sultanı "Moğollar güçlüdür" ifâdesini yasaklar ve böyle diyenleri sert bir şekilde cezalandırır.

Moğolların Anadolu coğrafyasında temsilcisi olan ve ilginç bir siyâsetçi olan Muinuddin Süleyman Pervâne 1270'li yılların başında Moğol komutanları ile sürekli bir didişme içerisinde olur. Pervâne, Memlûklerin güçlenmesinden etkilenerek Moğol valilerinden kurtulmak için Baybars ile irtibata geçer. Pervane Anadolu'daki bazı beyliklerden de cesaret alarak Sultân Baybars'1 Anadolu'ya davet eder. Baybars bu daveti hemen kabul etmemekle birlikte 1277 senesinde davete icâbet eder. Halep'te ordularını toplayan Memlûk Sultânı buradan Ayntab'a gelir ve Elbistan ovasında gerçekleşen savaşı kazanır. Sultân bu zaferin ardından Kayserî'ye gelir ve Selçuklu tahtına oturur. Burada bir hafta kalan Baybars adına para basitırır ve hutbe okutur. ${ }^{5}$

Memlûkler tarafından mağlup edilen İlhanlılar her şeye rağmen yaklaşık 80 sene hâkimiyetlerini sürdürebilmiştir. Kayserî'nin Memlûkler'in bu başarısından sonra Mısır'a tahsil için gittiği söylenebilir. Onun Mısır'a gittiğine dair malûmât olmakla birlikte hangi târihte gittiği pek belli değildir. Gelibolulu Mustafa Alî'nin Künhü'l-

5 Bkz. Cüneyt Kanat, "Baybars Zamanında Memlûk-İlhanlı Münâsebetleri (1260-1277)”, Tarih Incelemeleri Dergisi 16 (2001): 32-33,43-44. 
Ahbâr'ına göre Kayserî, medreselerde ilk eğitim sayılan "muhtasarât" derslerini tamamladıktan sonra Mısır'a gitmiştir. ${ }^{6}$ Kayserî'nin Mısır'da kaç sene kaldığı belli değildir. Misır seferinden sonra 1314 senesinde onun Niksar'da olduğunu bazı yazma kaynaklardan yola çıkarak öğrenebiliyoruz. ${ }^{7}$

\section{Niksar Günleri (İlhanlı Emirleri Dönemi):}

Dâvûd-i Kayserî'nin Niksar'daki hayatıyla ilgili bilgileri, yukarıda da bahsettiğimiz üzere İhsan Fazlıoğlu'nun bir kaç yazma eserin üzerinde bulduğu bazı kayıtlardan öğreniyoruz. İhsan Fazlıoğlu'nun İbn-i Sartak'ın Risâletü'l-Usûli'l-Asliyye fî'l-Hendese ve Kitâbü'l-İkmâli'l-Asîlî fî'l-Hendese isimli eserlerinin Kahire Üniversitesi 23209/1 23209/2 numarada bulunan mecmûadan yola çıkarak yaptığı araştırmalar neticesinde şu bilgiler ortaya çıkmıştır:

-Dâvûd-i Kayserî’nin 1314 senesinin Kasım ayında, 1315 senesinin Haziran ayında Tokat-Niksar'da bulunmaktadır.

- Dâvûd-i Kayserî'nin yukarıda ismi geçen yazma risâlelerin zahriyesinde müellif İbn-i Sartak için kullandığı "Mevlânâ ve Seyyidünâ" ta'bîrleri, onun İbn-i Sartak'tan TokatNiksar'daki Nizâmiye Medresesi'nde ders aldığını ortaya koymaktadır.

- Kayserî bu dönemde matematik ve astronomi gibi ilimlerle meşgul olmakta, yaş olarak da tahmînen 50-54 yaşlarındadır. ${ }^{8}$

$\mathrm{Bu}$ dönemde Tokat yöresi Moğol-İlhanlı emirlerinden Esentimur Oğlu Nureddîn ve Anadolu'nun Genel Valisi İrencin Noyan tarafından idâre edilmektedir. İlhanlıların kurucusu Hülagü'nün emriyle kurulan Merağa matematik-astronomi okulunun kurucusu Nasireddin Tûsî'nin (v. 1274) ikinci oğlu Asîlüddin Hasan'ın (v. 1315) yakın dostu olan ve Merağa Rasathanesi'nde çalışan Şemsüddîn Muhammed b. Sartak b. Çoban b. Şîrkîr el-Merâğî Tokat-Niksar Nizâmiyye Medresesi'nde matematik ve astronomi dersleri vermektedir. Dâvûd-i Kayserî'de onun talebesi olarak burada bulunmakta ve ilgili dersleri tahsîl etmektedir.

Burada dikkatleri çekmemiz gereken bir nokta da yukarıda bahsedilen ve Kayserî tarafından istinsâh edilen risâlelerin Mısır'da Kahire Üniversitesi Kütüphanesi'nde bulunmasıdır. $\mathrm{Bu}$ durum bize Memlûkler'in bölgeye gelmesi ve Moğollar'a darbe vurmasından sonra bölgede bulunan bazı eserlerin ve âlimlerin Mısır'a götürülmesi ihtimalini hatırlatmaktadır. Bu arada dikkati çeken bir gerçeklik de Dâvûd-i Kayserî’nin Tebrîz'de Reb'i-Reşîdî'de yazdığı ve istinsah ettiği eserlerin İstanbul Kütüphanelerinde bulunmasıdır. $\mathrm{Bu}$ eserler muhtemelen ya İlhanlıların yıkılışı ile birlikte Osmanlı coğrafyasına gelen âlimler ve devlet adamlarıyla beraber getirilmiştir ya da Yavuz Sultan Selîm'in 1514 Tebrîz Seferi ile birlikte elde edilmiştir.

Dâvûd-i Kayserî ile ilgili yapılan çalışmaların pek çoğunda onun hocası Abdürrezzâk-1 Kāşanî ile Sâve şehrinde veya Anadolu'da Konya şehrinde tanıştığı yazılmaktadır. Kanaatimize göre bu tanışma Sâve'de değil Tebrîz'de Reb'-i Reşî̀î Hankāh'ında gerçekleşmiştir. Bu karşılaşma ve hoca-talebe ilişkisini "Kāşânî-Kayserî İrtibâtı" bölümünde izâh etmeye çalışacağız.

\section{Dâvud-i Kayserî ve Reb'-i Reşîdî Kampüsü (İlhanlılar Dönemi):}

\footnotetext{
${ }^{6}$ Bkz. Özdemir, Dâvud-i Kayserî'de Varlık, Bilgi ve Insan, 28.

${ }^{7}$ Bkz. Özdemir, Dâvud-i Kayserî'de Varlık, Bilgi ve İnsan, 36.

${ }^{8}$ Bkz. Fazlıŏglu, Osmanlı Coğrafyasında İlmî Hayâtın Teşekkülü ve Dâvud el- Kayserî (656 “660”/1258

“1262”-751/1350, (İbnü'l-Arabî Geleneği ve Dâvûd-i Kayseri kitabı içerisinde. Hzr: Turan Koç), 26-38.
} 
Dâvûd-i Kayserî büyük bir ihtimalle Niksar'dan sonra İlhanlılar'1n ilim ve idâre merkezi olan Tebrîz'e Reb'-i Reşîdî Hankāhı'na gitmiştir. Kayserî'nin Reb'-i Reşî̂î̀ye gittiği konusu net iken hangi sene içerisinde buraya gittiğine dair elimizde net bir bilgi bulunmamaktadır. Fakat onun Tebrîz'de istinsah ettiği Menâzilü's-Sâirîn nüshası üzerindeki kayıttan elde ettiğimiz bilgiden yola çıkarak kendisinin 1324 yılında Tebrîz'de olduğunu öğreniyoruz. ${ }^{9}$

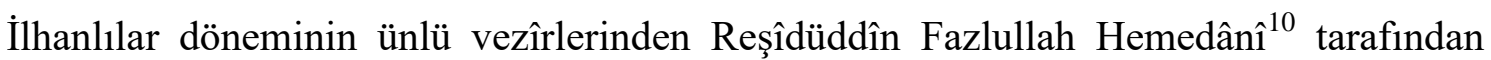
kurulan Reb'-i Reşîdî kampüsü Bağdat'ın Nizâmiye Medresesi hükmündedir. Reşîdüddin-i Tabîb diye de bilen Fazlûllah Hemedânî devlet adamlığının yanı sıra iyi bir doktor, iyi bir târihçi ve iyi bir düşünürdür aynı zamanda. Farsça, Arapça, Türkçe, Moğolca, Çince ve İbrânîce gibi dilleri bilen Hemedânî İlhanlıların devlet sistemini kurmada ön planda yer alan bir vezîrdir. Selçuklular için Nizâmülmülk neyse İlhanlılar için de Reşîüuddin odur âdetâ. Çok ilginç ve çok trajik bir hayata sahib olan bu vezîr İslâmî ilimlerin gelişmesi için çok büyük çabalar sarfetmiş ve Moğol saldırılarında darmadağın olan İ̉slâm âleminin yaralarını sarma çabası içerisinde olmuştur.

Reşîdüddîn, ilk önce Reb'-i Reşîlî Külliyesi'ni Tebrîz'in Kûh-i Veylân yamacında inşâ etmeye başlar ve katledilmesinden üç yıl önce 715 senesinde bu külliyeyi tamamlar. $\mathrm{Bu}$ külliye içerisinde kanallar yaptırır, dârüşşifâ, medrese ve kütüphâne gibi imârethâneler te'sîs eder. Bu binâların etrafinda evler kurar, bu evlerin çoğalmasıyla külliye zamanla bir şehir hâlini alır. Maalesef yüzyıllar sonra şiddetli savaşlar neticesinde bu şehir yerle bir olur. Günümüzde çok az kalıntıları kalabilmiştir.

"Reşîdîyye"ve "Reşîdâbâd" olarak da isimlendirilen Reb'-i Reşîdî Eğitim Şehri'nde; 30.000 güzel ev, 1500 kadar dükkân, 24 büyük kervânsarây, 200 hâfiz için dârülhuffâz, sûfîler için hankāh, 6000 talebe için talebe mahallesi, devlet adamlarını karşılamak için saray, bahçeler, hamamlar, emtia ambarları, değirmenler, kumaş- kâğıt imâlâthâneleri, darbhâneler, eczâhâneler kurulur. "Kûçe-i ulemâ" adında yalnız âlimlerin evlerinin bulunduğu bir câdde düzenlenir. Bu caddedeki kütüphâne 60.000 cilt kitap ile zamânının en önemli kütüphânelerinden birisi hâline gelir. Hindistan, Çin ve Mısır gibi dünyanın pek çok bölgesinden getirilen 500 doktor ile büyük bir hastane kurulur.

Reşîdüddîn kendi adına kurduğu Reb'-i Reşîdî ile kalmaz İlhanlı Hükümdârı Gâzân Hân adına Sultaniyye semtinde bir üniversite daha kurar. Burada da binlerce âlimi bir araya getirir ve 400.000 ciltlik bir kütüphâne te'sîs eder. Şâfiî ve Hanefîlere medrese, Sûfîlere Hankāh, Eşrâf'a Dârü's-Siyâde, Astronomi âlimlerine Rasathâne, Tabîblere Dârü'şŞifâ, Felsefecilere Hikmetiyye, gibi müesseseler inşâ eder.

Reşîdüddin Fazlullah, İslâm Âlemi'nin pek çok yerinden âlimleri cem' eder ve burada onlara iyi imkânlar sunar. Akademisyen değiş tokuşu, kitap yazımı, kütüphane, kâğıt fabrikası ve benzeri unsurlarla günümüz üniversitelerini aratmayan bir müessese kurar.

\footnotetext{
${ }^{9}$ Menâzilü's-Sâirîn'in Dâvûd el-Kayserî nüshasının tanıtımı için bkz. Abdurrezzak Tek, "Bir Müstensih Olarak Dâvûd-i Kayserî: Menâzilü’s-Sâirîn Örneği” (Uluslararası Dâvûd el-Kayserî Sempozyumu, Bursa, 2015). İlgili bölümü gönderen Abdurrezzak Tek Bey’e teşekkür ederiz.

${ }^{10}$ Reşî̉üddîn Tabîb Hemedânî dine dâir meselelerde İmâm-1 Gazzâlî’ye güvenmiş ve onun ilim yolunu tâkip etmeye çalışmıştır. Reşîdüddîn inşâ ettiği Reb'1-Reşîdî’de aklî ilimlerin yanında tasavvûfî ilimlere çok önem vermiş fakat felsefe çalışmalarını yasaklamıştır (bkz. Ebû'l-Fazl b. Ebi'l-Hayr Reşîdüddîn Fazlullah Hemedânî, Vakıfnâme-yi Rab'-ı Reşî̀dî, -Tahran: Encümen-I Âsâr-I Millî, 1350/1952)- 173). Reşîüddîn Fazlullah, İbnü'l-Havvâm, Adudüddin el-Î́cî, Abdurrezzâk-1 Kâşânî, Dâvûd-i Kayserî gibi pek çok büyük alimi himâye etmiştir. Câmi 'u't-Tevârîh, Şu'ab-i Pengâne, Âsâr $\hat{u}$ İhyâ, Tavzîhât-ı Reşîdî, Kitâbü's-Sultâniyye, Letâifü'l-Hakāik, Vakıfnâme-i Reb'i-Reşîlî, Miftâhü't-Tefâsîr gibi pek çok önemli eseri bulunmaktadır. (Bkz.Güdenli, "Reşîdüddîn Tabîb", 35: 19-21.)
} 
Reb'-i Reşîdî kampüsü Vezîr Reşîdüddîn'in vezirliği döneminde bizzat oğlu Ğıyâsüddin Muhammed tarafindan idâre edilir. Reşîdüddîn'in 17 Temmuz 1318 yılında öldürülmesiyle birlikte Reb'-i Reşîdî bir süre sahipsiz kalır. 1327 senesinden itibâren Reşîdüddîn'in oğlu Ğıyâsüddîn Muhammed İlhanlı vezîri olur ve 1335 senesine kadar süren bu vezîrliği esnasında babasının ilim ve âlimler konusundaki hassasiyetini sürdürür. Ğıyâseddîn, Reb'-i Reşîdî'ye pek çok şehirden âlimi dâvet eder. Dâvûd-i Kayserî'nin de bunlar arasında bulunması büyük ihtimaldir. Zîrâ Kayserî eselerinin önemli bir kısmını Reb'-i Reşîdî'de kaleme alır ve Muttala' isimli Fusûs Şerhi'ni bu vezîre ithâf eder.

Yazma eserler kütüphânelerinde ve târîhî kaynaklarda, âlim-sûfî-dost olan Reşîuüddîn ve oğlu Ğıyasüddîn'e ithâf edilen pek çok esere rastlayabiliyoruz. Baba-oğul vezîrlere eser ithâf eden zâtlar arasında; Kutbüddîn Şîrâzî, Kutbüddîn Râzî, Abdürrezzâk-1 Kāşânî, Dâvûd-i Kayserî, Sadrüddin Muhammed Türka, Adududdîn Îcî, Hamdullah-1 Kazvînî, Hâcû-yi Kirmânî, Selmân Savcî, Fahrüddin Mahmûd İbn-i Yemîn, Evhadî-yi Merâğî, gibi ünlü âlim ve ârifler bulunmaktadır.

\section{Abdürrezzâk-ı Kāşânî ile Dâvûd-i Kayserî İrtibâtı (İlhanlılar'ın Son Dönemleri):}

Dâvûd-i Kayserî'nin tasavvuf ilmine yönelmesi ve bu alanda eserler te'lîf etmeye başlaması Abdürrezzâk-1 Kāşânî ile tanışmasıyla başlar. Kayserî’nin hangi târihte Kāşânî ile tanıştığına dair net bir bilgi elimizde yoktur. Yukarıda da bahsi geçtiği üzere onun 1324 senesinde Tebrîz'de olduğunu bilebiliyoruz. Onun, hocası Kāşânî'nin üzerine şerh yazdığı Menâzilü's-Sâirîn isimli eseri istinsâh etmesi ve bu nüsha üzerine hocasının şerhinden bâzı iktibâslar yapması, Tebrîz'de talebelik yaptığını göstermektedir. Kayserî, Füsûs Şerhi'ni 1332 yılında kaleme aldığına ve bu şerhi Kāşânî'nin Fusûs ve Te'vîlât derslerine katıldıktan sonra te'lîf ettiğine göre onun uzun yıllar Tebrîz'de kaldığını söyleyebiliriz.

Şimdi Kayserî'nin bizzat kendi eliyle yazdığı Fusûs Şerhi'nden yola çıkarak bazı mâlûmâtı incelemeye tâbi tutalım. Kayserî, Füsûs Şerhi'nin giriş bölümünde 1. varakın "a" k1smında şöyle der:

$$
\begin{aligned}
& \text { وأيّدني التأييد الربّاني بإعلامرموزهوالتوفيق الصمد اني باعطاء كنوزه وساقتني الأقدار إلى خدمة مولانا الإمام العلاّمة الكامل المكمِل }
\end{aligned}
$$

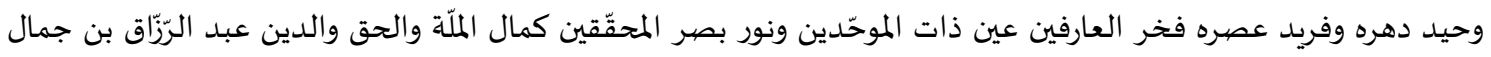

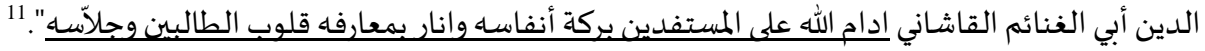

Rabbimizin inayetiyle Fusûs'un sırlarını zâhir kılmaya muvaffak oldum. Samed olan Allah beni onun hâzinelerini açmaya muvaffak kıldı. Kaderin cilvesi efendimiz, büyügümüz, büyük âlim, hem kâmil hem mükemmil zât, vaktin biriciği, asrın yegânesi, irfân ehlinin övüncü, tevhîd ehlinin hadekası, ve tahkik ehlinin kalb gözlerinin nuru milleti kemâle erdiren hakk1 ve dîni yüce tutan Abdurrezzâk bin Cemâleddin bin Ebi'lGanâim el-Kâşânî'nin yanına vardım. Cenâb-1 Hak bereketli nefeslerini ondan yararlananlara ziyâde ve devamlı kılsın. Öğrencilerinin ve sohbetine oturanların gönüllerini de onun irfânıyla nûrlu kılsın.

Allah onun bereket-i enfâsını istifâde edenler üzerine dâim kılsın. Talebelerinin ve sohbetinde oturanlarının kalblerini de onun ma'rifetleri ile münevver kılsın.

\footnotetext{
${ }^{11}$ Bkz. Dâvûd b. Mahmûd b. Muhammed el-Kayserî, Fusûsi'l-Hikem (Müttalau Husûsi'l-Kilem fỉ Şerhi Fusûsi'l- Hikem), 2. Bs (Tahran: Şirket-i İntişâât-i İlmî ve Ferhengî, 1383); Kayserî, Müttalau Husûsi'lKelim fì Şerhi Fusûsi'l-Hikem, 1-a.
} 
Bu cümlelerinden anlaşılan:

- Kaderin bazı hâdisâtı Kayserî’yi Reb'-i Reşîdî’ye getirmiş ve Kāşânî’nin rahle-i tedrîsine vardırmış.

- Kayserî bu şerhini yazarken hocası Kāşânî henüz hayattadır.

- Kāşânî burada ders halakalarında talebelere ve müridlere ta'lîmde bulunmaktadır.

- Kāşânî irfânî ilimler ile uğraşmakta ve Kayserî ondan istifâde etmektedir.

Kayserî, eserinin 1. varakının "b” kısmında da:

Bu eseri "Müttala'u Husûsi'l-Kelim fì Ma'ânî Fusûsi'l-Hikem” şeklinde adlandırdım. (...) Büyük devlet adamı, Milletin ve dînin yardımcısı Emîr Muhammed b. Sadri's-Saîd eş-Şehîd el-Merhûm el-Măgfûr Reşî̀ü'd-Dünya ve'd-Dîn'in talebi üzere yazdım. Allah seleflerinin kabirlerini nûrlu haleflerinin kudretini de kuvvetli kllsin. Yönetimine yardım edenleri ve yüce dostlarını da azîz kılsın. ${ }^{12}$

Bu cümlelerden anlaşılan:

- Kayserî bu eserini İlhanlı vezîri Ğıyâsüddîn Muhammed'in isteği üzerine kaleme almıştır.

- Ğıyâsüddîn Muhammed'in babası Reşîdüddîn Fazlullah, Kayserî tarafından övgüyle anlatılmaktadır.

- Ğyâsüddîn Muhammmed, İlhanlı Devleti'nde önemli bir kademede yer almaktadir.

Dâvûd-i Kayserî ilgili şerhinin 128. varakının "b" kısmında da:

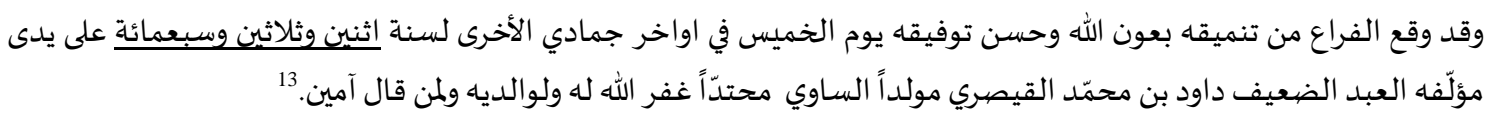

Bu şerhi, mahtiden (aslen) Sâve'li mevliden Kayserili olan Dâvud b. Muhammed elKayserî (Allah onun, âbâ û ümmehâtını ve âmîn diyenlerin günahlarını bağışlasın) tarafından Allah'ın tevfîk ve inâyetiyle 732 yılının Cemâziyelâhir ayının âhirinde Perşembe günü kaleme alınmıştır.

Bu ifâdelerden anlaşılan:

- Dâvûd-i Kayserî aslen Sâve'li olup Kayserî'de doğmuştur.

- Şârih, 26 Mart 1332 târihinde Fusûs Şerhi'ni tamamlamıştır.

Kāşânî'nin Dâvûd el-Kayserî üzerinde dikkat çeken bir te'sîr de yazdığı şerhlerin aynı eserler üzerinde olmasıdır. Kāşânî hem İbnü'l-Arabî hem İbnü'l-Farıd'ın eserlerini şerhettiği gibi Kayserî de bahsi geçen eserleri şerh etmiş. Kayserî'nin dört adet şerh şeklinde eseri bulunmaktadır. Bunların üçü hocasının şerh ettiği eserler ile aynı iken birisi de hocasının Te'vîlât isimli eserinin besmele kısmı ile ilgilidir.

İbnü'l-Arabî'nin Fusûsü'l-Hikem'ine mukaddime yazma adeti Kâşânî ile başlar. Kayserî de hocasını taklîd ederek Fusûs'a on iki mukaddime kaleme alır. Bunlar Fusûs için yazılan mukaddemelerin en meşhuru olur.

Hem Kâşânî hem Dâvûd-i Kayserî şerhlerini Reb'i-Reşîdî hankahında kaleme alır ve aynı kişiye ithâf ederler.

\footnotetext{
${ }^{12}$ Kayserî, Müttalau Husûsi'l-Kelim fì Şerhi Fusûsi'l-Hikem, 1-b.

${ }^{13}$ Kayserî, Müttalau Husûsi'l-Kelim fỉ Şerhi Fusûsi'l-Hikem, 128-b.
} 
Dâvûd-i Kayserî ve Abdürrezzâk-1 Kāşânî ile Reb'-i Reşîdî'de görüşen bir ârif de Bâbâ Rüknâ-yı Şîrazî'dir. Şîrâzî'nin de hocaları Kayserî ve Kāşanî gibi Füsûs üzerine şerhi bulunmaktadır Şîrâzî 769 senesinin Rebiülevvel'inde Isfâhân'da vefât etmiş ve şimdilerde Bâbâ Rüknâ Kabristânı diye meşhûr olan tarîhî türbede defnedilmiştir. ${ }^{14}$

Bâbâ Rüknâ-yı Şîrâzî, Kāşânî ve Kayserî’den Fusûs tahsîlini eserinin mukaddemesinde şu ifâdelerle belirtir:

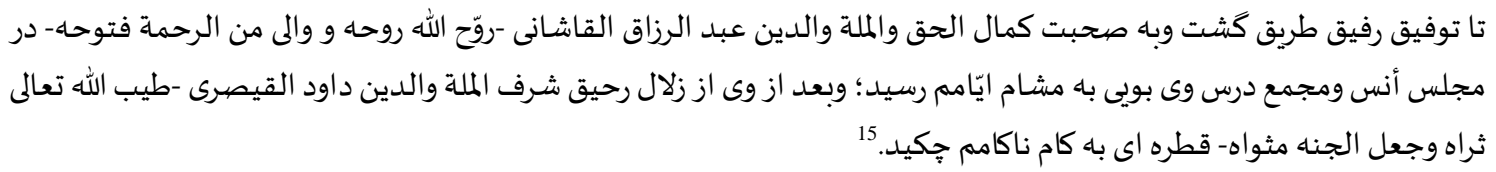

Allah'in inayetiyle yolumuz Kemâlü'l-Hakki ve'l-Milleti ve'd-Dîn Abdurrezzâk elKāşânî'nin (Allah rûhunu tervîh buyursun ve futûhunu da rahmetle desteklesin) sohbetine düşünce onun ünsiyet meclisi ve ders topluluğuna vartp ondan istifâde ettim. Onun ardindan Şerefü'l-Milleti ve'd-Dîn Dâvûd el-Kayserî'nin (Allah türbesini güzelliklere bürüsün ve yerini de cennet yapsin) mârifet şarâbından bir katre tattım.

Gıyâseddin Muhammed b. Reşîdüddin Fazlullah, dönemin kaynaklarına göre, ilimle ve alimlerle çok dost olan bir devlet yöneticisiydi. Sühreverd seyyidlerinden birinin kızı olan Fâtima Hâtûn ile evlenen Gıyâseddin için, kitap ve şiirler kaleme alınmış ve eserler ithâf edilmiştir. Meselâ: Şerh Muhtasar İbn Hâcib, Metn-i Mevâkıf, Kavâid-i Glyâsiyye (Adududdin el-Îcî'tarafından), Şerh-i Metâli', Şerh-i Şemsiyye, Târîh-i Güzîde (Hamdullah Kazvînî tarafından). ${ }^{16}$

G1yâseddin Muhammed, kendisi gibi âlimleri ve şâirleri çok seven ve onlara hürmet gösteren Ebû Saîd Bahâdır Hân öldükten sonra bâzı ihtilâflardan dolayı Emîr Alî tarafından 736 senesinin Ramazân ayında öldürülmüştür. ${ }^{17}$

İlhânlıların son önemli hükümdârı olan Bahâdır Hân aynı zamanda şâir, mûsîkîşinas ve hattâttı. Müslümanların gönlünü kazanabilen Ebû Saîd Bahâdır ilim adamlarına hürmet eder ve adalete dikkat ederdi. Abdürrezzâk-1 Kāşânî, Bahâdır Hân'1 çok severdi. Hattâ onun hakkında iki kasîdesi mevcûttur. ${ }^{18}$

Vezîr Giyâseddin Muhâmmed, Abdürrezzak Kāşânî, Dâvûd-i Kayserî, Evhaduddin-i Kirmânî, Sadraddin Hammuya, Hamdullah Kazvînî, Alâüddevle-i Simnânî, Safiyuddin Erdebîlî gibi zatlar tarafından çokça övülmüştür. İstanbul yazma eserler kütüphanelerinde Gıyâseddin Kütüphânesi için kaleme alınmış kıymetli minyatürlü eserler vadır. ${ }^{19}$ Safidî, Gyyâseddin Muhammed'i Selçuklu vezîri Nizâmülmülk ile karşılaştırmış, âdetâ onu İlhânlılar'ın Nizâmülmülk'ü olarak görmüştür. ${ }^{20}$ Devlet idâresi

14 Bkz. Celâleddin Hümâyî Rükneddin-i Şîrâzî Bâbâ, Nusûsu'l-Husûs fî Tercümeti'l-Fusûs (Tahran: Dânişgâh-1 Tahrân, 1980), 1-15.

${ }^{15}$ Bkz. Rükneddin-i Şîrâzî, Nusûsu'l-Husûs fî Tercümeti'l-Fusûs, 4.

${ }^{16}$ Abdurrahim Alkış, Abdürrezzâk Kāşân̂̂̀ ve Şerhü Fusûsü'l-Hikem İsimli Eserinin Tahkik ve Tahlîli (Doktora, MÜSBE, 2008), 58.

17 Bkz. Alî Ekber Dihhudâ, Luğatnâme, (zîr nazar-i Muhammed Muîn-Seyyid Ca'fer Şehîdî) (Tahran: Dânişgâh-i Tahrân, 1341), 20: 392-393.

18 Abdulkadir Yuvalı, "I.A”, . Ebû Saîd Bahâdır Hân (İstanbul: Türkiye Diyanet Vakfi, 1994), 10: 218 219; Alkış, Abdürrezzâk Kāşânî ve Şerhü Fusûsü'l-Hikem İsimli Eserinin Tahkik ve Tahlîli, 57.

19 Bkz. Zeki Velidî Toğan, "İ.A", Reşî̉ü̈ddin Tabîb (Ankara: Milli Eğitim Bakanlığı, 1964), 9: 708; Dihhudâ, Luğatnâme, (zîr nazar-i Muhammed Muîn-Seyyid Ca'fer Şehîdî), 20: 392-393; Peter Jackson Charles Melville, "Ğ̄āțt-al-Dīn Moḩammad", Encyclopcédia Iranica (New York: Bibliotheca Persica Press, 2001), 10: 599.

${ }^{20}$ Bkz. Jackson - Melville, “Ğīâț-al-Dīn Moḩammad”, 10: 598. 
ve yapılan ilmî faaliyetler göz önüne alındığında aslında Reşîdüddin-i Hemedânî, İlhânlılar'da Selçuklular'ın Nizâmülmülk'üne; Abdürrezzâk-1 Kāşânî de geniş ders halakası, nüfûzu ve eserleri ile Reb'-i Reşîdî medreselerinin Gazzâlî'sine müâdildir. 6000 talebesi ve büyük kütüphânesi ile Reb'-i Reşîdî Medreseleri etkisi bakımında Nizâmiye Medreseleri seviyesindedir. ${ }^{21}$

Asrımız araştımacılarından Celâleddin Aştiyânî ve Muhammed Hâcevî vb. pek çok yazar Kayserî'nin Konya ve Mısır'da ilim tahsil ettiğinden yola çıkarak Kāşânî’nin Mısır, Şâm ve Konya'ya ilmî seferler yaptığı ve buralarda ilim meclislerinde dersler îfâ ettiklerini iddia etseler de buna işâret eden güvenilir bir bilgi yoktur. ${ }^{22}$ Aștiyânî ayrıca Kāşânî'nin bu seferlerden sonra memleketi Kâşân'a döndüğünü ve orada bir köye çekilip orada bir kütüphâne kurduğunu belirtir. ${ }^{23}$ Kanâatimizce Dâvûd-i Kayserî’nin Kâşânî'ye talebe olması Tebrîz'de gerçekleşmiştir. Zîrâ Reb'-i Reşîdî kurulduktan sonra Reşîdüddin-i Hemedânî İslâm âleminin birçok yerinden ünlü âlimleri dâvet etmiş ve onlara önemli imkânlar sunmuştu. ${ }^{24}$

Abdurrezzâk Kāşânî'nin Reb'-i Reşîdî'de kaleme aldığı eserler içerisinde en eski târihlisi olanı 727 yılında te'lîf edilen bir Hakāiku't-Te'vîl isimli eseridir. Bundan dolayı, onun bu târihlerde Reb'-i Reşîdî'de bulunduğunu söyleyebiliriz. Çünkü yazar bu nüshada kitabını nerede ne zaman kaleme aldığını belirtmiştir. Ayrıca ders halakasında bulunan Muhammed b. Mahmûd el-Hayrebertî adındakı öğrencisinin bu nüshaya yazdıkları ta'lîkleri bulunmaktadır. ${ }^{25}$ Abdurrezzâk-1 Kāşânî Fusûsu'l-Hikem Şerhi'ni 730 senesinde mezkûr hânkāhta yazmış ve bu eserini ders kitâbı olarak talebe halakasında okutmuştur. Hayrebertî 731 senesinde istinsâh etmiş ve bu nüshâyı müellifin ders halakasında ona okuduğunu ifâde etmiştir.

Dâvûd-i Kayserî ayrıca hocasının Te'vîlât'ından bismillâh bölümünü Şerhu'l-Besmele min Te'vîlâti'l-Kâşânîyye ismiyle şerh etmiş ve bu kısa risâlenin girişinde şu ifâdeleri kullanmıştır:

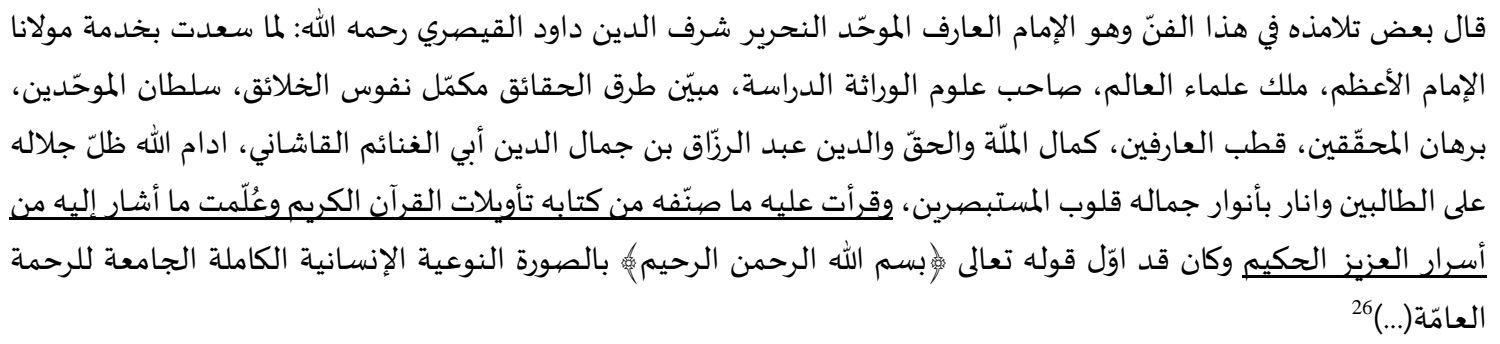

\footnotetext{
${ }^{21}$ Alkış, Abdürrezzâk Kāşânî ve Şerhü Fusûsü'l-Hikem İsimli Eserinin Tahkik ve Tahlîli, 58.

${ }^{22}$ Bkz. Celâlüddin Aştiyânî, Dâvûd-i Kayserî'nin Şerhu Fusûsi'l-Hikem'i için mukaddeme (Tahran: Şirket-i İntişâât-i İlmî ve Ferhengî, 1383), 4; Celâleddin Hümâyî Rükneddin-i Şîrâzî Bâbâ, Saîduddin Fergânî Meşâriku'd-Derârî̀'si (Şerhu Tâiyye İbn Fârıd) için mukaddeme (Meşhed: Encümen-i Felsefe ve İrfân, 1987), 3; Muhammed Hâcevî, Sadreddin-i Konevî'nin el-Fükûk'ü için mukaddeme (İntişârât-1 Mevlâ, 1371), 40.

${ }^{23}$ Bkz.Aştiyânî, Dâvûd-i Kayserî'nin Şerhu Fusûsi 'l-Hikem 'i için mukaddeme, 4.

${ }^{24}$ Alkış, Abdürrezzâk Kāşânî ve Şerhü Fusûsü'l-Hikem İsimli Eserinin Tahkik ve Tahlîli, $68 .$.

${ }^{25}$ Bkz. Abdürrezzâk Kāşânî, Şerhu Fusûsi 'l-Hikem, Slm. Ktp. Mahmud Paşa blm. no:18.

${ }^{26}$ Bkz. Dâvûd b. Mahmûd b. Muhammed el-Kayserî, Şerhu'l-Besmele min Te'vîlâti'l-Kâşânîyye, nr. no: 2061, 6-a.
} 
Bu beyanlardan da Dâvûd-i Kayserî'nin Abdurrezzâk-1 Kāşânî'den Te'vîlâtu'l-Kur'ân dersleri aldığını anlayabiliyoruz. Bundan ortaya çıkıyor ki Kayserî uzun bir müddet Kāşânî'nin derslerine devâm etmiştir. ${ }^{27}$

\section{Dâvûd-i Kayserî İznik’te (Osmanlıların Hâkimiyet Dönemi)}

Selçuklu Devleti'nin İlhanlı hâkimiyetine girmesiyle Anadolu'da Türk beylikleri kurulmuştur. $\mathrm{Bu}$ beyliklerin coğrafî ve beşerî olarak en küçükler arasında yer alan Osmanlı Beyliği zamanla imparatorluk hâlini alacaktır. Bu beyliğin kısa süre içerisinde büyümesinde devlet teşkilatının büyük rolü vardır. Başta Herbert Adams Gibbons olmak üzere bâzı müsteşrik bilim adamları Osmanlıların devlet yapılanmasını Bizanslılar' dan aldıkları iddiasındadırlar. ${ }^{28}$ Mehmet Fuat Köprülü ve Halil İnalcık gibi târihçiler ise Osmanlıların devlet teşkilatını İlhanlılardan aldıkları kanâatindedirler. ${ }^{29}$ İlhanlıların yıkılmasından sonra bu devletin pek çok yetkili ve etkin isminin Osmanlı hâkimiyetindeki coğrafyaya geçmesi ve devlet yönetiminde etkin olması ikinci şıkk1 ciddi bir şekilde desteklemektedir. Hatta Dâvûd-i Kayserî’yi de bu sürecin ilmî cihetine bir numune olarak kabul edebiliriz. Osmanlıların kuruluş döneminde, bilhassa mâlî konularda İlhanlılardan etkilendiği apaçıktır. Çünkü İlhanlı mâliyesine ait "Sa'âdetnâme", Kānûnü's-Sa'âdet, Risâle-i Sâhibiyye, Câmi'u'l-Hisâb, Risâle-i Felekiyye, Şemsü's-Sibâk" gibi temel eserler Osmanlılarca istinsâh edilmiştir. Bu eserlerden Risâle-i Felekiyye içerisinde İlhanlılar'ın muhâsebe usûllerine, devlete bağlı vilâyet ve uç beyliklerin yıllık vergilerine, çeşitlerine ve tahsîl edilme şekillerine ait bilgiler bulmak mümkündür. Ayrıca Selçuklu ve İlhanlı idârî sistemlerinde çalışan tecrübeli bâzı isimlerin Osmanlılarca istihdâm edildiğini görüyoruz. Tıpkı Dâvûd-i Kayserî gibi. Orhan Gâzî 1326 senesinde Bursa'yı fethedinceye kadar İlhanlılar'a bağlı bir uç beyi konumundadır. Bursa'nın fethi ile birlikte Orhan Gâzî idâre ve ekonomi de bağımsız faaliyetlerde bulunacaktır. Öncelerinde para darbında İlhanlı sultanı Gâzân Hân'in emirlerine uyan ve Tebrîz miskāline göre davranan Orhan Gâzî, sonralarında Bursa'da yaptırdığı Câmi'nin kitâbesine "Emir-i Kebîr" ve bastırdığı paranın üzerine de "Orhân bin Osmân" yazısını yazdırmıştır. ${ }^{30}$ Tabîatiyle bu durumun gerçekleşmesinde İlhanlılar'ın yavaş yavaş zayıflamasının etkisi vardır. Orhan Gâzî İznik şehrini 1331 târihinde ele geçirdiğinde ise İlhanlılar iyice zayıflamış bir durumda ve yıkılmak üzereydi. Orhan Gazî bu firsattan istifâde ile Anadolu ve İran coğrafyasından pek çok bilgin ve ereni İznik ve Bursa'ya dâvet etmiştir. Bu bilginler ve erenler sâyesinde İslâmlaşma hareketleri de hızlanmıştır. ${ }^{31}$

Ünlü târihçi Josef von Hammer, Osmanlı Târihi isimli eserinde Orhan Gâzî dönemini, Osmanlı Devleti'nin kuruluşu ve gelişmesini anlatırken tarîkatların, şeyh ve dervişlerin mezarlarının kahraman ve fâtihlerin mezarı kadar önemli olduğunu vurgular. ${ }^{32}$ Dâvûd-i Kayserî’nin mezarı Osmanlılar döneminde önemli bir ziyaret yeri iken 1938'de, pek çok

\footnotetext{
${ }^{27}$ Alk1ş, Abdürrezzâk Kāşânî ve Şerhü Fusûsü'l-Hikem İsimli Eserinin Tahkik ve Tahlîli, 72.

${ }^{28}$ Bkz. Herbert Adams Gibbons, Osmanlı Imparatorluğunun Kuruluşu (Ankara: 21. Yüzyıl Yayınları, 1998), 10-44; 150-215.

${ }^{29}$ Bkz. Fuad Köprülü, Osmanlı Devletinin Kuruluşu, 4. Bs (Ankara: Türk Tarih Kurumu Basımevi, 1991), 23; Halil İnalc1k, The Question of the Emergence of the Ottoman State/Osmanl Devleti'nin Kuruluş Sorunu (İnternational Journal of Turkish Studies, 1980), 71-79; Süleyman Demirci, "Erken Dönem Osmanlı Târihi 'Kara Delik'mi? Osmanlı Devletininin Kuruluşu 'Gâzî/Gazâ' İdeolojisi ile İlgili Tartışmalar" 1/5 (2013): 89-100.

${ }^{30}$ Bkz. Yuvalı, "İ.A”, 10: 249-254..

${ }^{31}$ Bursa'nın İslamlaşma süreci için bkz. Osman Çetin, Sicillere Göre Bursa'da İhtida Hareketleri ve Sosyal Sonuçları (1472-1909), 2. Bs (An: TTK Yayınları, 1999), 15-16,23.

32 Bkz. Joseph von Hammer, Osmanlı Tarihi, trc. Mehmet Ata (İstanbul: MEB Yayınları, 1991), 20.
} 
şehirde olduğu gibi, İznik’te de belediyecilik işleri çerçevesinde yol yapılmış ve bu durum hazretin uzun bir süre unutulmasına neden olmuştur.

Davûd-i Kayserî’nin Başmüderris olduğu İznik Medreseleri kuruluşu tamamlandığında (1335-36) İlhanlı devletinin târihe karıştığını görüyoruz. 1335 senesi; İlhanlılar'ın âlim ve ârifleri çok seven sultanı Ebu Saîd Bahadır Hân'ın, Reb'-i Reşî̂î Kampüsü'nün yöneticisi de olan Kayserî'nin yakın dostu olan vezîr Ğıyâsüddin Muhammed b. Reşîdüddin'in ve Kayserî'nin hocası Abdürrezzâk-1 Kāşânî'nin vefât yılıdır aynı zamanda. İlhanlıların yıkılışı ve dostlarının vefâtı Kayserî'nin Anadolu'ya yeniden gelmesinde en önemli etkenler olsa gerek.

Dâvûd-i Kayserî, Selçuklu, Misır ve İlhanlı coğrafyasında öğrendiklerini ve buralardan elde ettiği tecrübeleri Osmanlı Devleti döneminde pratikte uygulamaya koymuş ve Osmanlı Eğitim teşkilatının öncülüğünü yapmıştır. Kendisinden sonra Sirâceddîn-i Ürmevî'nin talebesi olan Tâceddîn-i Kürdî medrese teşkilatının başına geçmiş ve aynı çizgiyi devâm ettirmiştir.

\section{SONUÇ}

Osmanlı medreselerinin kurucu müderrisi olan Dâvûd-i Kayserî çok zorlu bir dönemde Anadolu, Mısır ve İran coğrafyasında iyi bir eğitim görmüş ve bu eğitiminin semerelerini Osmanlı Medreseleri'ne nakletmiştir. Hayatı hakkında az bilgi sahibi olduğumuz Kayserî ile ilgili bâzı bilgileri yazma nüshalar üzerindeki kayıtlardan öğrenebiliyoruz. Bu kayıtlardan elde ettiğimiz bilgiler çerçevesinde onun on yılı aşkın bir süre İlhanlılar'ın başkenti Tebrîz'de Reb'-i Reşîlî hankâhında kaldığını söyleyebiliriz. Kayserî, tasavvuf ile ilgili tahsîlini Reb'-i Reşîî Hankāhı'nda görmüş irfânî eserlerinin çoğunu burada kaleme almıştır. Eserlerinin önemli bir kısmını Reşîdüddîn Fazlullah-1 Hemedânî'nin oğlu Ğıyâseddin Muhammed'e ithâf etmiştir. İlhanlı devleti yıkılınca yeni gelişmekte olan Osmanlı Beyliği kontrolünde olan İznik'e gelmiş ve Osmanlı Medreseleri'nin kurulmasına öncülük etmiştir. Onun kurduğu bu medrese teşkilatı yüzyıllarca aynı minvâlde varlığını sürdürmüştür. Dâvûd-i Kayserî gibi aynı zamanda sûfî olan bir şahsiyetin medrese kurucusu olması Osmanlı medreselerinin tasavvuf eksenli medreseler olmasına neden olmuştur. Kendisinden sonra gelen Molla Fenârîler, Molla Gürânîler, Akşemseddînler onun yolunu tâkip etmiştir. 


\section{KAYNAKÇA}

Alkış, Abdurrahim. Abdürrezzâk Kāşânî ve Şerhü Fusûsü'l-Hikem İsimli Eserinin Tahkik ve Tahlîli. Doktora, MÜSBE, 2008.

Aştiyânî, Celâlüddin. Dâvûd-i Kayserî'nin Şerhu Fusûsi'l-Hikem'i için mukaddeme. Tahran: Şirket-i İntişârât-i İlmî ve Ferhengî, 1383.

Çetin, Osman. Sicillere Göre Bursa'da Ihtida Hareketleri ve Sosyal Sonuçlarl (14721909). 2. Bs. An: TTK Yayınları, 1999.

Demirci, Süleyman. "Erken Dönem Osmanlı Târihi 'Kara Delik'mi? Osmanlı Devletininin Kuruluşu 'Gâzî/Gazâ' İdeolojisi ile İlgili Tartışmalar' 1/5 (2013).

Dihhudâ, Alî Ekber. Luğatnâme, (zîr nazar-i Muhammed Muîn-Seyyid Ca'fer Şehîdî). Tahran: Dânişgâh-i Tahrân, 1341.

Fazlıoğlu, Osman. Osmanlı Coğrafyasında İlmî Hayâtın Teşekkülü ve Dâvud elKayserî (656 “660”/1258 “1262”-751/1350, (İbnü'l-Arabî Geleneği ve Dâvûd-i Kayseri kitabı içerisinde. Hzr: Turan Koç). İstanbul: İnsan Yayınları, 2011.

Gibbons, Herbert Adams. Osmanlı Imparatorluğunun Kuruluşu. Ankara: 21. Yüzyıl Yayınlar1, 1998.

Güdenli, Osman Gazi. "Reşîdüddîn Tabîb". DİA. İstanbul: Türkiye Diyanet Vakfi, 2008.

Hâcevî, Muhammed. Sadreddin-i Konevî'nin el-Fükûk'ü için mukaddeme. İntişârât-1 Mevlâ, 1371.

Hammer, Joseph von. Osmanlı Tarihi. Trc. Mehmet Ata. İstanbul: MEB Yayınları, 1991.

Hemedânî, Ebû'l-Fazl b. Ebi’l-Hayr Reşîdüddîn Fazlullah. Vakıfnâme-yi Rab 'ı Reşîdî. Tahran: Encümen-i Âsâr-i Millî, 1350/1952

İnalc1k, Halil. The Question of the Emergence of the Ottoman State/Osmanlı Devleti'nin Kuruluş Sorunu. İnternational Journal of Turkish Studies, 1980.

Jackson, Peter - Melville, Charles. "Ğīāț-al-Dīn Moḩammad”. Encyclopódia Iranica. New York: Bibliotheca Persica Press, 2001.

Kanat, Cüneyt. "Baybars Zamanında Memlûk-İlhanlı Münâsebetleri (1260-1277)”. ), Tarih Incelemeleri Dergisi 16 (2001).

Kayserî, Dâvûd b. Mahmûd b. Muhammed el-. Fusûsi'l-Hikem (Müttalau Husûsi'lKilem fî Şerhi Fusûsi'l- Hikem). 2. Bs. Tahran: Şirket-i İntişârât-i İlmî ve Ferhengî, 1383.

Kayserî, Dâvûd b. Mahmûd b. Muhammed el-. Müttalau Husûsi'l-Kelim fî Şerhi Fusûsi'l-Hikem. no: 512.

Kayserî, Dâvûd b. Mahmûd b. Muhammed el-. Şerhu'l-Besmele min Te'vîlâti'lKâşânîyye. no: 2061.

Köprülü, Fuad. Osmanlı Devletinin Kuruluşu. 4. Bs. Ankara: Türk Tarih Kurumu Basımevi, 1991.

Özdemir, Sema. Dâvud-i Kayserî’de Varlık, Bilgi ve İnsan. İstanbul: Nefes Yayınları, 2014.

Rükneddin-i Şîrâzî, Celâleddin Hümâyî, Bâbâ. Nusûsu'l-Husûs fî Tercümeti’l-Fusûs. Tahran: Dânişgâh-1 Tahrân, 1980.

Rükneddin-i Şîrâzî, Celâleddin Hümâyî, Bâbâ. Saîduddin Fergânî Meşâriku'd-Derârî'si (Şerhu Tâiyye İbn Fârıd) için mukaddeme. Meşhed: Encümen-i Felsefe ve İrfân, 1987.

Tek, Abdurrezzak. "Bir Müstensih Olarak Dâvûd-i Kayserî: Menâzilü's-Sâirîn Örneği”. Bursa, 2015.

Toğan, Zeki Velidî. “İ.A”. Reşîdüddin Tabîb. Ankara: Milli Eğitim Bakanlığı, 1964. 
Yuvalı, Abdulkadir. “İ.A”. . Eb̂̂ Saîd Bahâdır Hân. İstanbul: Türkiye Diyanet Vakfi, 1994. 